\title{
Karl Barth
}

\section{IZ ZADNJIH SPISOV}

\section{How my mind has changed 1960 Ad limina Apostolorum 1967}

\section{Pojasnilo}

Leto 1968 je bilo tudi leto smrti Karla Bartha, enega najpomembnejših teologov 2o. stoletja, ki je s svojim delom izzval in zaznamoval ne le protestantsko, ampak zaresno krščansko teološko misel sploh. Izziva jo tudi danes in prepričan sem, da jo bo tudi v prihodnje. Njegovo Pismo Rimljanom iz leta 1922 je bilo silovit ugovor tedanji usmeritvi in razvoju protestantske (in katoliške) teologije, njegova Cerkvena dogmatika, ki jo je pisal vse življenje (in je narasla na 12 zvezkov in več tisoč strani), je ponovno in na novo govorila o Bogu in/kot Božji besedi, Božjem razodetju in krščanski veri, o vseh tradicionalnih krščanskih »temah" in dogmah. Ni bilo in ni mogoče iti mimo njegovih formulacij - in argumentacij - da »religija ni vera, ampak nevera«, da je »Bog Bog in človek človek«, da je med njima s človeške strani nepremostljiva razlika, da pa hkrati Bog(a) ni brez človeka in zato tudi ni in ne more biti do kraja brez-božnega človeka, človeka brez Boga. Veljal je in velja za kritika prilagajanja/podrejanja teologije »moderni misli«, po drugi strani pa so mnogi prepričani, da je prav njegova teologija bistven in nepogrešljiv vidik moderne in postmoderne misli oziroma prispevek $\mathrm{k}$ njej (bila naj bi med drugim na primer teološka pred-hodnica in vzporednica Derridaju).

Barth je bil eden vodilnih pobudnikov in avtorjev protinacistične Barmenske teološke deklaracije nemških protestantov leta 1934 (Stati inu obstati 17-18, 2013). Vse od mladih let - ko je bil že pred prvo svetovno 
vojno »tako liberalen, da je postal socialdemokrat« - ni skrival svoje socialistične usmerjenosti.

Umrl je 10. decembra 1968 v rojstnem Baslu, kjer je tudi pokopan.

V slovenščini imamo doslej eno knjižno predstavitev njegovega dela in življenja (Marko Kerševan, Vstop v krščanstvo drugače: protestantska teologija Karla Bartha v našem času in prostoru (Ljubljana: CZ, 1992)) in prevode treh njegovih (krajših) del:

- Karl Barth, Kratka razlaga Pisma Rimljanom, uvodna beseda Matjaž Črnivec (Ljubljana: Logos, 2002).

- »Razodetje, Biblija, teologija: polemika med Adolfom von Harnackom in Karlom Barthom, "Poligrafi 21/22, letnik 6, 2001.

- Karl Barth, »Skupnost kristjanov in skupnost državljanov, "Stati inu obstati 12, št. 23-24 (2016): 263-94.

Ob 50-letnici smrti objavljamo dvoje spisov iz njegovih zadnjih let: avtobiografsko predstavitev njegovega življenja in dela v desetletju 19481958 in Barthov zapis o svojem srečanju z dokumenti in protagonisti 2. vatikanskega koncila leta 1966.

\section{Kako sem se spreminjal (1948-1958) ${ }^{1}$}

Leta 1958 sem bil s strani revije Christian Century že tretjič izzvan, da poročam, kaj sem v minulem desetletju doživel, izkusil, premislil in storil novega - ali na nov način -, ne da bi postal nekdo drug, ampak ostal isti, tisti, kot sem vedno bil in tudi vedno bom. Tako poročilo ne more biti več kot dodatek (parergon), spremljan z marsikakšno skušnja-

1 Barthov zapis je izšel najprej v reviji The Christian Century 77 (1960) pod naslovom »How My Mind Has Changed «. Skupaj z Barthovima "poročiloma« za desetletji 1928-1938 in 1938-1948 je izšel v knjigi How I Changed my Mind (Richmond: John Knox Press, 1962). Naš prevod je po nemški verziji iz izdaje: Karl Barth, »Der Götze wackelt«: Zeitkritische Aufsätze, Reden und Briefe von 1930 bis 1960 (Berlin: Kathe Vogt Verlag, 1961). Vsa pojasnila v oglatih oklepajih so prevajalčeva. 
vo in nikakor ne nujen. Toda ker ga od mene želijo, zakaj ne bi poskusil z njim? Pa naj bo!

Najprej nekaj osebnega. Danes obstaja gerontologija kot posebna znanost o (z)možnostih starega človeka. Sam sem zdaj, leta1958, postal notorično star človek. Zame je najpomembnejši dosežek te znanosti spoznanje, da je najbolje, če se o svojem staranju in starosti razmišlja, kolikor je le mogoče malo - razen o tistem najnujnejšem, to je praktično neizogibnem - in mirno nadaljuje biti človek. Leta, ko sem lahko jahal konja ali ko sem še zmogel skromne vojaške napore in spretnosti, o katerih sem pisal v zadnjem poročilu, so seveda že daleč za mano. Vzpenjanje v gore (Pridigar 12,5) mi ni več čisti užitek. Tudi tempo za delovno mizo je opazno počasnejši. Glede na tožbe mnogih iz moje generacije pa sem lahko hvaležen, da me ni napadla še nobena od meni poznanih bolezni in da mi zrak, voda, smiselna prehrana in zmerno gibanje pomagajo ostati čil ter mi tudi zvesta pipa še vedno dobro dene, in mi jo zato moj modri zdravnik ni prepovedal, ampak dovolil. Seveda pa mislim, da sta med zemeljskimi dejavniki k ohranjanju takega mojega zunanjega stanja največ pripomogla dva med seboj povezana razloga: moja Cerkvena dogmatika, ki kliče po nadaljevanju in po končanju in mi torej ne dovoljuje, da bi povesil glavo in roke; in potem povabilo baselskega mestnega sveta, naj nadaljujem s predavanji na univerzi preko običajne starostne meje 65 let - tako sem vedno znova vznemirjan in poživljan s pričakovanji študentske mladosti. $Z$ enim stavkom: za najboljše zemeljsko gibalo - ki ga zdaj bolj kot kdajkoli potrebujem - se moram zahvaliti prav "trudu in delu«, o katerem govori 9o. psalm. Kako dolgo bo še tako, ne vem. Toda $\mathrm{v}$ zadnjih desetih letih, $\mathrm{v}$ času mojega prehoda iz sedmega $\mathrm{v}$ osmo desetletje, je tako bilo.

$\mathrm{Ob}$ naraščajočem razumevanju za zgodovinskost vsega človeškega bivanja in tudi svoje lastne eksistence sem se naučil, da moram postati bolj pozoren in ljubeč do svojih vezi z bližnjimi: $z$ bolj oddaljenimi predniki in $\mathrm{z}$ vedno toplejšo udeleženostjo v življenju svojih otrok in vnukov. Posebej me veseli, da sta $v$ tem desetletju tudi moja sinova postala univerzitetna profesorja teologije. Eden se ukvarja z Novo zavezo v daljnem Chicagu, drugi s Staro zavezo v še bolj oddaljeni Džakarti. Pogrešam 
njuno vzpodbudno navzočnost, saj vesta in znata toliko stvari, ki se jih sam zdaj ne bom nikoli naučil. Tolaži pa me naše soglasje in drzna misel, da zdaj sonce vsaj enega iz našega rodu vedno najde budnega pri služenju najlepši od vseh znanosti. Moj najmlajši vnuk, rojen v Indoneziji, je pravkar prispel z letalom na obisk. Ime mu je Daniel. Star je dva meseca, a me že razveseljuje $z$ opaznimi znaki inteligentnosti, muzikaličnosti in pobožnosti ...

In zdaj o političnih zadevah. Moj odnos do njih mi že v prejšnjih časih ni ravno olajšal življenja. V tem desetletju me je zapletel v nove težave. Kaj se je dogajalo? Kaj sem storil? Kaj se mi je zgodilo?

Vprašanje Vzhod - Zahod je nas vse in tudi mene spremljalo vse od konca II. svetovne vojne. Prav pri tem vprašanju se nisem mogel pridružiti veliki večini ljudi, ki me obdajajo. Nikakor nisem naklonjen vzhodnemu komunizmu, tako kot se nam do sedaj kaže; zelo cenim, da mi ni treba živeti na njegovem območju in nikomur ne želim, da bi bil k temu primoran. Ne vidim pa, da bi bilo politično ali celo krščansko primerno ali dovoljeno iz takega zavračanja izvajati posledice, kakršne so se vedno ostreje izvajale v zadnjih 15 letih na Zahodu. Načelni antikomunizem imam za še večje zlo od komunizma samega. Ali lahko zanikamo, da je komunizem nedobrodošel, toda v vsej svoji spačenosti naravni rezultat in protiigra zahodnega razvoja? Ali ne straši totalna, gotovo nečloveška prisila - ki mu jo najbolj očitamo - v drugačni podobi že od nekdaj tudi v naših, domnevno svobodnih zahodnih družbah in državnih ureditvah? In ali je kaj novega in vredno posebnega zgražanja to, da ima komunizem sam sebe za nauk o odrešenju, ki naj bi osrečil vse ljudi in narode in se zato razširil po vsem svetu? Ali ne obstajajo tudi drugi sistemi take vrste in $\mathrm{z}$ isto tendenco? Ali res mislimo, da lahko ljudstvom, ki jih obvladuje, in svetu, ki ga ogroža - ali posameznikom, ki trpijo njegove posledice -, pomagamo s tem, da razglašamo in prakticiramo nasproti njemu izključno sovražnost kot edino možnost? Ali smo pozabili, da gre pri tej absolutni sovražnosti - ki naj bi ji bil na Zahodu zavezan vsak dobronameren človek in ki naj bi se kazala pri vsakem in v vsem - za tipičen izum in dediščino naših lastnih nekdanjih diktatorjev, da je morda načelni antikomunist le »Hitler v nas«? Dalje: ali se je 
na Zahodu kdo potrudil, da bi mučni položaj, ki je nastal po letu 1945, premislil iz zornega kota vzhodnega, posebej ruskega stališča? Ali nismo bili, in to upravičeno, veseli sovjetskega prispevka k zmagi nad nacionalsocialistično nevarnostjo? Ali niso zahodni voditelji proti koncu vojne Sovjetski zvezi uradno priznali in garantirali določen vpliv v vzhodni Evropi? To so gotovo storili zaradi takratne pretirane potrebe po varnosti; toda ali je ob vsem, kar se je zgodilo po letu 1914, res tako težko razumeti, da je SZ takrat ponujeno poizkušala obdržati in utrditi? S kakšno pravico se je po letu 1945 na Zahodu kmalu začelo govoriti o nujnem roll back (potiskanje nazaj)? Ali je bilo res neizogibno, da se je v predvidljivem nasprotovanju druge strani takemu roll back takoj videlo vojaško ofenzivno ogrožanje preostalega sveta? Ali ni bilo druge izbire kot to, da se je vzhodnega partnerja do skrajne meje izzivalo z robustnim zahodnim obrambnim zavezništvom (Nato), z obkrožanjem z vojaškimi postojankami, z ustanavljanjem ZR Nemčije kot iztegnjene pesti pred njegovim nosom, $\mathrm{z}$ njeno ponovno oborožitvijo in nuklearnim orožjem na njenem ozemlju - in s tem v gotovo ne manjši meri okrepilo njegovo lastno zlobnost in izzvalo nasilne protiukrepe? Ali Zahod končno res ni znal drugega, kot da se je zanašal na svoje ostudne atomske in vodikove bombe, in ali ni bilo zato prav, da je moral zvedeti, da na tem področju tudi druga stran ni bila več nedejavna in neuspešna? Ali proti temu ni bilo boljše diplomacije, kot je ta, ki je, kot je videti, ves svet zmanevrirala v slepo ulico?

In dalje: kakšna je ta zahodna filozofija, politična etika in žal tudi teologija, ki je zahodnega »človeka organizacije « prepesnila v angela luči, vzhodnega »kolektivnega človeka " pa v angela teme in potem s pomočjo take metafizike ter mitologije dala absurdnemu toku hladne vojne potrebni višji blagoslov? Nobenega opravičila ni, da se je podobno v nasprotni smeri počelo tudi na Vzhodu. Ali zahodne stvari in odporne moči zahodnega človeka res ni bilo mogoče zagotoviti drugače kot s postavljanjem pred nesmiselno alternativo: ali svoboda in človekovo dostojanstvo ali medsebojno atomsko uničenje - pri čemer se je poizkušalo slednje za vsak slučaj že v naprej predstaviti kot dejanje prave krščanske ljubezni do bližnjega? V tej norišnici - ne morem reči drugače - se v vseh teh 
letih na noben način nisem mogel najti. Mislim, da se je v njej iz golega strahu pred ognjem neodgovorno igralo z ognjem. Mislim, da bi Zahod $\mathrm{v}$ gotovo potrebnem kritičnem soočenju $\mathrm{z}$ močjo in ideologijo Vzhoda moral iskati in najti boljše poti, kot so tiste, ki jih je ubiral doslej. V teh letih so se mu več kot enkrat ponudile možnosti za dostojno, razsodno in varno vodeno politiko koeksistence in nevtralizacije. Ime »svobodnega sveta«, s katerim se postavlja, bi bolje počastil, če bi prišel do uporabnejših in obetavnejših praktičnih rezultatov, kot so ti, pred katerimi danes stojimo. Mislim, da bi morala posebej zahodni tisk in literatura dokazati hvaljeno humanost Zahoda $\mathrm{z}$ mirno presojo in razumevanjem vzhodnih osebnosti in razmer v njihovi dialektični dejanskosti, namesto da se $z$ nehumanostjo sooča izrazito nehumano. Predvsem pa mislim, da bi bila naloga krščanskih Cerkva, da bi politično odgovornim voditeljem in javnemu mnenju pomagale s pričevanjem o miru in upanju na Božje kraljestvo. $Z$ dosedanjim nepremišljenim načinom, s katerim so stvar evangelija identificirale s prav tako slabo koncipirano in nespretno vodeno stvarjo Zahoda, so stvári evangelija prizadejale škodo, ki je po človeški presoji tudi $\mathrm{z}$ največjim ekumenskim in misijonarskim prizadevanjem še dolgo ne bo mogoče popraviti. Rim pri tem ni bil boljši od Ženeve in Ženeva ne boljša od Rima. Vzhodni brezbožnosti so ponudili nove, težke argumente, namesto da bi jo praktično zavrnili.

$\mathrm{Ko} /$ ker sem tako videl - in še vidim - stvari, sem se v teh letih moral večkrat izpostaviti: $v$ redkejših primerih, ko sem govoril, ko/ker so drugi molčali, večkrat pa, ker sem molčal, ko so drugi govorili. Če me že niso zato naravnost osumili za skritega komunista ali vsaj njihovega sopotnika, so me uvrstili med nevedne politične diletante ali (z obsojajočo primerjavo $z$ velikimi starozaveznimi preroki) med načelne nekonformiste, ki zlonamerno uživajo v epater le bourgeois [škandaliziranju malomeščanov].

Stokrat so mi očitali flagrantno osebno protislovje, ki naj bi bilo v tem, da nočem tudi nasproti komunizmu ponoviti tistega, kar sem rekel proti nacionalsocializmu. Obtožili so me črne nehvaležnosti do prednosti in dobrodejnosti svobodnega sveta. Moje izjave in še posebej moje neizjave so nabili na sramotilni steber kot dokumente nevarnega po- 
mehkuženja in zmede (razložljive samo z mojo visoko starostjo!). V vodilnih političnih in cerkvenih krogih Zahodne Nemčije sem postal še nepopularnejši, kot sem bil sicer tudi že v mojih najboljših časih. $\mathrm{Na}$ drugi strani pa so mi tudi z nekaterih sovjetsko-nemških uradnih mest dali na znanje, da zastopam izrecno "antidemokratične«, prav »antihumanistične« nazore. Še posebej slabo mi je šlo v moji švicarski domovini, kjer je za čuda mnogo malih McCarthyjev - leta 1951 je vodilni politik (zdaj že umrli) proti meni sprožil pravo kampanjo. Tudi kasneje, posebej v času madžarske krize [okrog leta 1956] in ob priliki čudne diskusije o švicarski atomski oborožitvi sem moral poslušati, da sem dvomljiv član švicarske skupnosti in da sem povsem zapravil zmerne simpatije, ki sem si jih pridobil za časa Hitlerja. In kdo me je že zaradi mojega molčanja ob Madžarski obdolžil, da se nisem zmožen pokesati, kot se je Jean Paul Sartre, in da odpiram prostor za nezaslišani in nekrščanski resentiment proti - Ameriki? Oh, že kar vidim nekrologe, kjer bo v povzetku rečeno, da imam nekaj zaslug pri prenovitvi teologije in vsekakor v cerkvenem boju v Nemčiji, da pa sem bil s političnega vidika nevarna blodna luč!

To je, kar se mi je zgodilo na tem, političnem polju: gotovo nikakršno mučeništvo, vsekakor sploh nič strašnega, nad čemer bi se lahko utemeljeno pritoževal, pa vendar vznemirjenje, ki me je dejansko spremljalo in zaposlovalo vse desetletje in ki ga zato tudi opisujem. Starejši ko postajam, bolj sem prepričan, da je pri takih napadih - če se ima mirno/čisto vest - bolje, da se ne zagovarja in opravičuje prav vneto, še bolje pa, da se sploh ne zagovarja in opravičuje: zadeve se prej ali slej same pokažejo $\mathrm{v}$ pravi luči in pravih razmerjih. Zato tega tudi tu ne bom poskušal. To pišem na dan zadnjih novic o Nixonovem obisku v Moskvi in nameravanem srečanju Hruščova in Eisenhowerja. Berem jih brez optimizma, a tudi brez vnaprejšnje skepse, glede na to, kaj vse bi se še lahko zgodilo v odnosih med Vzhodom in Zahodom, ljudmi in narodi, silami in ideologijami. Kako bi bilo, ko bi se nesrečno obdobje Dulles - Adenauer nekoč končalo? Kako, ko bi se nemški luterani odvrnili od svojih dosedanjih slabih poti? Kako, ko bi nekega dne iz Vatikana ali Ženeve namesto brezobveznih splošnosti zaslišali preroško-apostolsko besedo kesanja in 
miru? Komaj si upam upati kaj takega. Toda zakaj naj bi bilo izključeno, da se nekaj takega ali podobnega vendarle lahko zgodi še pred koncem časov in novim začetkov vseh stvari?

Moral sem biti o teh zadevah nekoliko izčrpnejši, kot sem pravzaprav hotel in kot bi bilo primerno glede na težo, ki jo imajo v mojem življenju. Moj pravi interes je tudi v tem obdobju veljal moji nekoč prevzeti in na določen način opravljani nalogi na posebnem teološkem področju. Tako sem pri delu na Cerkveni dogmatiki prišel od prikaza krščanske etike (s katerim sem sklenil nauk o stvarjenju) k nauku o spravi in s tem k živi sredici vseh problemov teološkega spoznavanja. Tudi tu - in tu še posebej - je bilo treba mnogo na novo in sveže premisliti in predstaviti, kar se da zvesto in pozorno sledeč pričevanju Stare in Nove zaveze in v kar se da odprtem soočenju s starejšo in novejšo tradicijo. Cilj še ni dosežen in ne vem, če ga bom dosegel. Lahko pa rečem, da je najvišja gora na poti do njega že za mano - in tako tudi za bralca. Napor, ki ga zahteva, zato ni manjši. Zdi pa se mi, da se splača: vedno znova se čutim poklicanega, da nadaljujem, ker hoče biti pri tem udeleženih toliko ljudi, učečih se hkrati z mano. Zavedam se, da mi gre tudi s tega vidika nezasluženo dobro. Prevoda dela v angleščino in francoščino dobro napredujeta in tudi prevod $v$ japonščino se je obetajoče začel. Od daleč ne morem vedeti, kako bo delo sprejeto $v$ teh širših prostorih, ko bo preseženo prvo presenečenje in začudenje. Njegov tok pa tudi z drugega vidika spremljam kot tista kokoš, ki je naenkrat opazila, da »njena« račka plava. Število člankov, spisov, disertacij in celotnih knjig, ki se ukvarjajo z mojim delom, je vidno raslo in raste. $Z$ njimi pa tudi množica hipotez o razumevanju in strukturi v njem predstavljene teologije: iz njih večkrat izvem o sebi več, kot bi si drznil sanjati. Še bolj kot ta vrsta pozornosti in upoštevanja me veseli, ko vedno znova slišim, da je Cerkvena dogmatika brana in študirana tudi v župniščih (pa čeprav tu in tam preprosto kot priročnik) za potrebe pridige, pouka in duhovne oskrbe ter da tako pride tudi v širšo versko skupnost. Mislim pa, da je njen dejanski učinek tako $\mathrm{v}$ akademski vedi kot v cerkvenem pridiganju vendarle omejen in da bo tako tudi ostalo. Na obeh področjih se je mogoče izogniti njenemu napotilu in sporočilu: bodisi tako, da se ju sploh ne vzame v obzir, bodisi 
tako, da se z njima opravi na osnovi »rekla kazala« ali bežnega vtisa, še preden bi se ju zares lotili, bodisi tako, da se iz njene usmeritve in vsebine nekaj izbrska, da bi se to pomešalo s povsem drugače usmerjenimi koncepcijami ter tako trivializiralo, predvsem pa izognilo bistvenemu in odločilnemu. Ker pa sem lahko hvaležen za toliko zaresne pozornosti, se tudi nad tem ne smem in nočem pritoževati. Na področju teologije so imperialistični apetiti dvojno ostudna zadeva.

Med zadevami, ki so jih moji teološki sodobniki v teh letih tehtali in obravnavali, je tudi mene, kot mnoge druge, najbolj zaposlovala Bultmannova »demitologizacija Nove zaveze«: ne toliko zaradi konkretne problematike, temveč zato, ker je pomenila najizrazitejšo in najvplivnejšo obnovitev teme in metode tiste teologije, ki jo je navdihoval Schleiermacher. Bila mi je povod, da sem ponovno premislil, preveril in preciziral svoje izhodišče, ki sem ga pred 40 leti oblikoval prav v odmiku od te tradicije. Bultmannu končno nisem mogel slediti: ne njegovim konkretnim tezam in še manj njegovemu temeljnemu postopku, ki po mojem teologijo znova spravi v egiptovsko ali babilonsko ujetništvo neke filozofije. V komuniciranju s teološkim naraščajem univerze v Baslu se mi je zdelo, da bo interes za to eksistencialno interpretacijo relativno kmalu uplahnil - potem ko je bilo nekaj časa videti, da bo požrla vse druge, kot v starih časih historično-kritična interpretacija. Toda drugod lahko izgleda drugače in ne bi se čudil, če bi Bultmannova stvar imela še opazno bodočnost v oblikah, ki jih v vseh mogočih variantah razvijajo njegovi učenci. Gotovo moramo biti Bultmannu hvaležni za svarilo, da še dolgo ne do kraja izbojevane osvoboditve teologije iz omenjenega ujetništva ni tako lahko in enostavno ohraniti, kot bi si želeli predstavljati (tudi mnogi moji bralci in prijatelji). Nenavadno mi je bilo in mi je še vedno, da je današnja biblicistika Stare zaveze posebej ob stari in vedno novi temi »vera in zgodovina« na boljših poteh, kot so merodajni biblicisti Nove zaveze, ki so se na moje zaprepaščenje ponovno odpravili iskat "historičnega Jezusa", oboroženi z meči in koli. Pri tem nisem želel biti udeležen ne prej ne sedaj.

Posebne besede zahteva to, kar se je v tem desetletju dogajalo med rimsko katoliško teologijo in menoj. Ne glede, kaj se sicer o meni misli, 
mi je pripadel redek sloves, da od reformacije dalje noben evangeličanski teolog od nje ni bil deležen toliko kritike, a tudi pozitivne in resne obravnave. Nedvomno: najobsežnejše predstavitve, najpronicljivejše analize in tudi najzanimivejše presoje Cerkvene dogmatike in mojih drugih del so doslej prišle iz tega tabora (če odmislim pomembne izjeme, kot sta delo Berkouwerja in nova heidelberška disertacija mladega Američana). Vodilna je znana knjiga mojega prijatelja Hansa Ursa von Balthasarja. Soglašanje je bilo doslej vsaj v ravnotežju z zadržanostjo in nasprotovanjem. In zgodilo je, da je mladi Luzernčan [Hans Küng], ki se je sedem let zavzeto izobraževal v Rimu, promoviral v Parizu s knjigo, v kateri je $\mathrm{Z}$ vso ostrino pokazal, da prav v središčnem načelu, v nauku o opravičenju, med reformatorskim učenjem, kot sem ga razložil in predstavil, ter med prav razumljenim učenjem rimske Cerkve ni bistvene razlike. Knjige na katoliški strani $\mathrm{z}$ uradnega mesta nihče ni dezavuiral, različni prominentni predstavniki pa so jo izrecno pohvalili. Kaj naj rečem $\mathrm{k}$ temu? Ali je milenij že tu, ali čaka za bližnjim vogalom? Kako rad bi to verjel! Toda proglasitev svetega Lavrencija iz Brindisija, fanatičnega protireformacijskega kapucina iz 16. stoletja, za »doktorja Cerkve« (v istem rangu z Atanazijem, Avguštinom, Tomažem Akvinskim idr.), romanje milijonov katoličanov $\mathrm{k}$ »sveti [Jezusovi] suknji« v Trierju in blaga, čeprav glede substance vendarle manj kričeče siromašna, prva enciklika novega papeža [Janeza XXIII.] žal kažejo, da usmeritve rimske Cerkve še ne določajo glasniki teološke avantgarde, ki mi je naklonjena. Lahko pa ugotavljam, da taka avantgarda obstaja in deluje do sedaj brez prepovedi - kar za nas druge, vsekakor pa zame, pomeni lepo možnost, še več, nujnost, da z njo ostajamo v notranjem stiku.

Pri teološkem poučevanju v Baslu mi je poleg samega predavanja bilo čedalje pomembnejše neposredno sodelovanje $\mathrm{z}$ novimi in novimi letniki študentov. Mirno lahko rečem, da mi je v zadovoljstvo, ko se $\mathrm{z}$ njimi pogovarjam, poslušam njihova vprašanja in pripombe ter odgovarjam nanje, ko jih usmerjam na potí, ki jih imam za prave. To v seminarju počnem na primer pri študiju Luthrovih ali Calvinovih tekstov, a tudi Schleiermacherjevih, Bultmannovih, Tillichovih in tekstov drugih velikih mož modernega časa, tudi iz katoliških vrst; prav tako na 
vajah v nemškem, francoskem in angleškem jeziku ob različnih odlomkih iz prejšnjih zvezkov Cerkvene dogmatike. Vtis imam, da so študentje tudi s svoje strani še vedno radi in zavzeto zraven (čeprav je starostna razlika med mano in njimi vedno večja). Tudi to se bo spremenilo, toda do sedaj je tako.

Za bralce revije Christian Century bo posebej zanimivo slišati, da sem imel in še vedno imam prave prijatelje med mladimi in starejšimi Američani, ki zdaj kar številni prihajajo za nekaj semestrov ali tudi let na študij v Basel. Prihajajo iz različnih denominacij, a so se skoraj vsi zmogli resno in uspešno vživeti v naše tako drugačno duhovno vzdušje (ne nazadnje tudi tisto pri meni); kar nekaj njih se je častno vrnilo v domovino $\mathrm{z}$ baselskim doktoratom in so tam že sami postali docenti. Nihče od njih ni trpel zaradi antiameriškega kompleksa, ki se mi pripisuje. Prepričan sem, da sem tako tudi za Ameriko naredil več solidnega in koristnega, kot če bi - kot mnogi Evropejci - odpotoval tja in se dal tam občasno osebno videti in slišati. Da ne govorim o tem, da me v Ameriki na najboljši možen način avtentično in originalno zastopa moj sin kot profesor v Chicagu. Kdor pa hoče, me lahko zdaj tudi tam v miru prebira in študira $\mathrm{v}$ korektnih angleških prevodih.

Ko govorim o svojih dejavnostih v Baslu, naj še omenim, da je tukajšnji zapor postal prednostno mesto za moje občasne pridige. Verjetno je malo profesorjev teologije, katerih pridige lahko posluša le nekdo, ki je pred tem grdo prekoračil državljanski pravni red. Maja 1956 sem dosegel 70 let. Sprejel sem številne izraze prijateljstva od blizu in daleč; sprejel sem jih z zadovoljstvom in s hvaležnostjo Bogu ter ljudem in kot upam z dovolj odpora do skušnjave, da bi samega sebe imel za jubilanta in prepomembnega. Leto $1956 \mathrm{mi}$ je bilo še pomembnejše zaradi 20o-letnice rojstva Wolfganga Amadeusa Mozarta. Višek tega leta mi je bil, ko sem bil povabljen kot slavnostni govornik na proslavo te obletnice $\mathrm{v}$ Baslu. Nisem kaj posebno estetsko nadarjen in izobražen človek in poleg tega gotovo nisem naklonjen mešanju in izenačevanju zgodovine odrešenja in zgodovine umetnosti. Toda zlati zvoki Mozartove glasbe so me vedno znova żivo nagovarjali - ne kot evangelij, ampak kot prispodobe Kraljestva, ki ga oznanja evangelij Božje svobodne milosti. Brez njih si 
ne bi mogel misliti niti življenjskega desetletja, o katerem sem skušal nekaj povedati, niti tega, kar me je motiviralo osebno, $\mathrm{v}$ teologiji in $\mathrm{v}$ politiki. Gotovo je malo teoloških študijskih sob, v katerih bi na isti višini lahko drugo poleg druge videli sliki Calvina in Mozarta.

Iz nemščine prevedel Marko Kerševan

\section{Ad limina apostolorum ${ }^{2}$}

\section{Zgodovinsko poročilo}

Karl Barth je bil povabljen, da se kot zunanji opazovalec osebno udeleži zadnjega zasedanja 2. vatikanskega koncila leta 1965. Zaradi bolezni se takrat vabilu ni mogel odzvati. Zato je po končanem koncilu zaprosil, če bi se lahko post festum iz prve roke podučil o razumevanju in razlagi sprejetih koncilskih dokumentov. V Rimu je bila njegova prošnja $\mathrm{s}$ strani Sekretariata za edinost kristjanov sprejeta $\mathrm{z}$ razumevanjem in veseljem: Barth je tako "poromal ad limina Apostolorum «, na tradicionalni obisk grobov apostolov Petra in Pavla in papeža v Rim. Tu se je od 22. do 29. septembra 1966 srečal z več vidnimi akterji vatikanskega koncila, takrat vodilnimi kardinali in teologi, kot so bili kardinal Bea, škof Willebrand, jezuit Karl Rahner, dominikanec Yves Congar, (bodoči papež) Ratzinger, Semmelroth, a tudi s predstavniki konservativne, do koncilske usmeritve zadržane struje, kot je bil kardinal Ottaviani, s katerim se je pogovarjal na sedežu Svetega oficija, naslednika rimske inkvizicije. Dobrohotno, dobesedno z razširjenimi rokami - opiše Barth - ga je na dolg pogovor sprejel tudi papež Pavel VI. Barth poudarja pozornost in naklonjenost, s katero je bil sprejet, počastitve, ki jih je bil na

2 Vir: Karl Barth, Ad limina Apostolorum (Zürich: EVZ, 1967). Iz knjige objavljamo naš uredniški povzetek »Zgodovinskega poročila« (7-21), izbor »Vprašanj v Rimu« (23-43), »Pismo o mariologiji« (61-66); nismo prevedli in objavili razprave »Irenično-kritične pripombe $\mathrm{k}$ Dogmatični konstituciji 2. vatikanskega koncila o Božjem razodetju « (45-59). Vsa pojasnila v oglatih oklepajih so prevajalčeva.

3 Urednikov/prevajalčev povzetek Barthovega poročila o potovanju v Rim. 
tem sicer povsem zasebnem obisku deležen, poudarja, da je bilo vzdušje na srečanjih in pogovorih odprto, prijazno, vzpodbudno. Le na Papeški lateranski univerzi - očitno »bolj papeški od papeža« - ga niso hoteli sprejeti. Zato pa so bili toliko bolj odprti in spodbudni pogovori na jezuitski univerzi Gregoriana.

Za pogovore je Barth po temeljitem študiju koncilskih dokumentov pripravil pisna vprašanja dveh vrst: enih, pri katerih je želel preveriti ali dopolniti svoje razumevanje koncilskih dokumentov in v njih vsebovanih opredelitev, odločitev, presoj, in drugih, ki so izražala njegovo (teološko, evangeličansko-protestantsko) kritičnost do nekaterih opredelitev in presoj. Vprašanja so sogovorniki dobili v roke pisno, če je bilo potrebno $\mathrm{z}$ avtorjevimi sprotnimi ustnimi pojasnili. V običajno triurnih razgovorih ( $v$ francoščini) so izmenjali poglede; sporov in polemike se je Barth pri tem izogibal, saj, kot pravi, „v Rim gotovo nisem prišel, da bi se prepiral«.

Naklonjeno izpostavi osebnost papeža Pavla VI., »modrega in na svojevrsten način ponižno pobožnega človeka«, ki se je na koncilu in po njem znašel pred težavno nalogo, da hkrati skrbi za pravo svobodo in nujni red v katoliški cerkvi. Posebej da priznanje papeževemu pogumnemu in vztrajnemu prizadevanju za mir v Vietnamu in poudari, da tokrat Cerkev v Rimu - kot tudi v Ženevi - ni molčala in ni blagoslavljala orožja ...

Barth je na obisku dobil potrjen vtis, da je s koncilom tudi katoliška Cerkev v pravem in nepovratnem, čeprav ne vedno preglednem in včasih počasnem gibanju, ki bi bilo lahko v marsičem vzgled in spodbuda tudi protestantski strani. Upa, da reformatorji v katoliški Cerkvi pri prilagajanju mišljenja in delovanja modernemu svetu ne bodo ponovili napak novejšega protestantizma. »Papež ni Antikrist. Aparat tridentinskih anatem proti nam je skupaj z drugo staro opremo le še v Denzingerju“ [zbornik/arhiv uradnih cerkvenih dokumentov in stališčc. Potrebno je mirno in odločno nadaljevanje čiščenja, vsekakor najprej pred lastnim pragom. Spreobračanje iz ene Cerkve v drugo - v eni ali drugi smeri samo po sebi nima smisla. Smiselno je lahko le, ko pomeni neko nujno 
obliko konverzije h Kristusu, »Gospodu ene, svete, katoliške in apostolske Cerkve«, ne pa k neki drugi Cerkvi.

V knjigo Ad Limina Apostolorum je vključil pisna vprašanja, ki jih je pripravil za pogovore v Rimu. Ker je organizator, Sekretariat za krščansko edinost, vnaprej zagotovil popolno diskretnost pogovorov, ne objavlja odgovorov (ali neodgovorov) na postavljena vprašanja. Dodal je krajšo analizo nekaterih stališč koncilske "Konstitucije o Božjem razodetju «, ki jo je napisal za zbornik znanega avantgardnega koncilskega teologa Congarja. [V analizi ugotavlja prodor nove, reformaciji blizke pozicije o prvenstvu Svetega pisma (pred tradicijo) v tem dokumentu, kljub posameznim delom in formulacijam, ki vlečejo nazaj $k$ tridentinskemu koncilu. Zaradi prodora te usmeritve je/bo mogoče reči: »ta koncil je bil koncil reforme (str. 59).] Knjigo je sklenil z zasebnim pismom (neimenovanemu) katoliškemu teologu o mariologiji, ob katerem lahko »bojazljivci na naši strani uvidijo, da sem se iz Rima vrnil enako trmasto kljubovalno evangeličanski - raje bi pravzaprav rekel evangeličansko-katoliški -, kot sem odpotoval tja» (19).

\section{Vprašanja (v) Rimu ${ }^{4}$}

Konstitucija o liturgiji

Kritična vprašanja

1. Kaj pomeni » exercitium « [izvrševanje] odrešenjskega delovanja v liturgiji $(1,2 ; 1,6)$ ? Ali ne bi bil primernejši pojem liturgije kot središč-

4 Barth je o(b) izbranih koncilskih dokumentih pripravil in objavil dve vrsti vprašanj: najprej "vprašanja o pravilnem razumevanju« in nato »kritična vprašanja» (glej »Zgodovinsko poročilo« zgoraj). Prevedli smo vsa Barthova »kritična vprašanja« in samo tista "vprašanja za razumevanje«, iz katerih je dovolj razvidno njegovo lastno teološko stališče in/ali so nujna za razumevanje sledečih »kritičnih vprašanj«. Objavljamo, skratka, vprašanja, ki omogočajo dovolj jasno razbrati Barthova stališča in poglede na zadeve, ki jih in kakor jih obravnavajo izbrani dokumenti 2. vatikanskega koncila. Pri prevajanju latinskih besed(il), ki jih iz dokumentov navaja Barth, smo se oprli na: Koncilski odloki: konstitucije, odloki, izjave, poslanice 2. vatikanskega vesoljnega cerkvenega zbora (1962-1965): Slovenski prevod s splošnim uvodom in posebnimi uvodi k posameznim dokumentom (Ljubljana: Nadškofijski ordinariat, 1980). 
nega odgovora Božjega ljudstva [na Božje odrešiteljsko delo] ali kot njegovega pričevanja [o tem odrešujočem delu]?

2 Ali je Kristus navzoč pri maši samo v osebi duhovnika in v obeh evharističnih elementih $(7,1)$ - ko pa po točki 48 konstitucije kristjani immaculata hostia [brezmadežno hostijo] darujejo $z d r u z ̌ e n i ~ z d u$ hovnikom (una cum ipso)?

3. Kako je utemeljeno, da je obhajanje pod obema podobama obravnavano kot izjema (55) (razen pri obhajanju duhovnika samega)? Ali je za to dovolj že samo sklicevanje na Trident?

4. Ali je evharistično slavje v novozavezni občini že imelo dominanten pomen, ki se mu pripisuje tu in $\mathrm{v}$ drugih besedilih drugega vatikanskega koncila?

Dogmatična konstitucija o Cerkvi

Kritična vprašanja

1. Kje je distanca med Kristusom kot Gospodom, Kraljem in Sodnikom in njegovo Cerkvijo? So samo laiki njegovi pričevalci v svetu, »hierarhija « pa je več kot to ? Ali ni vsa Cerkev ljudstvo pričevalcev? Ali je Cerkev (pogl. 8,52) res razodetje in nadaljevanje inkarnacije?

2. Kako, da je med štirimi značilnostmi Cerkve iz Dejanj apostolov 2,42 (ohranjanje nauka apostolov, skupnost, lomljenje kruha, molitev) prav tretja (evharistija) označena kot konstitutivna za življenje Cerkve?

3. Ali res Cerkev naredi [erzeugt] ${ }^{5}$ vernike (pogl. 3,28; 8,64) ? S krstom?

4. Kje sta ob nakazovanju eshatološke razsežnosti cerkve (7,48-50; $8,65)$ Kristusov ponovni prihod in sojenje grešnikom? Kje je »novi Jeruzalem«, sveto mesto, ki bo prišlo od Boga iz nebes ( $\operatorname{Raz} 21,2)$ ne pa se povzpelo vanje? Kje je sploh novo stvarjenje (Teihard de Chardin)?!

5. So eksegeze, nakazane v poglavju $8,55-58$, dovolj trden temelj za mariologijo, ki je zgrajena na njih? In za (66) zahtevani poseben Marijin

5 V uporabljanem uradnem slovenskem prevodu dokumenta: »rodi« $(164,198)$. 
kult? Ali vsa ta zadeva (tako Karl Rahner) res sodi k središčnim krščanskim resnicam?

Dogmatična konstitucija o Božjem razodetju Kritična vprašanja

1. Če po 4 b Konstitucije ni nobenega novega "javnega razodetja« - tradicija je po 7 le predaja/izročanje in pričevanje razodetja, ki so ga prejeli in za katerega so pričali apostoli -, če tudi cerkveno učiteljstvo po $10 b$ ni nad Verbum Dei (po 24a=Pismo), ni nad Božjo besedo, ampak v njeni službi - zakaj je potem tradicija/izročilo (7b, 9a, 10a, 10c) pred Pismom, kako se potem pride do triade (tradicija/izročilo, Pismo, cerkveno učiteljstvo) in medsebojne odvisnosti treh sestavin - do prevzetja govora o "pari pietatis affectu ... ${ }^{6}$ iz dokumentov koncila v Trentu?

2. Če velja, kar je v 21c rečeno o Pismu, koliko je potem udeležba pri evharistiji rast (incrementum), "počastitev Božje besede« (»veneratio verbi Dei«) pa le spodbuda (impulsus) duhovnega življenje Cerkve?

Pastoralna konstitucija o Cerkvi v sedanjem svetu Kritična vprašanja

1. Ali prevladujoči optimizem konstitucije o razvojnih možnostih sveta ustreza tonu sinoptičnih evangelijev in pavlinskih pisem?

2 Ali je res tako gotovo, da je treba dati dialogu $s$ svetom prednost pred oznanjevanjem temu svetu?

3. Zakaj je v konstituciji tako malo konkretnih stališč? Kje je preroška funkcija koncila $\mathrm{v}$ realni problematiki sredine našega stoletja?

Odlok o ekumenizmu

Kritična vprašanja

1. Kaj pomeni $(1,2) »$ inter fratres quoque nostros sejunctos« [tudi med našimi ločenimi brati] - saj je ekumensko gibanje nastalo zunaj ka-

6 Omenjeni slovenski prevod: „vse skupaj, vsako na svoj način [...] učinkovito prispeva« (str. 372). 
toliške Cerkve in so $(4,1 ; 4,10 ; 24,2)$ katoličani šele pozvani k udeležbi v njem?

2. Zakaj ta prednost nekatoliških Cerkva $(3,2-4,7)$ ni izrecno priznana?

3. K 3,5: ali naj bi bila v 1 Kor 1,12 omenjena Petrova stranka nasproti trem drugim ena in edina popolna katoliška Cerkev?

4. Kaj pomeni za definicijo pojma ločeni bratje (pomanjkanje plenitudo/polnosti!), če je po 4,9 tudi sami katoliški Cerkvi težko uresničiti plenitudo catholicitatis [polnost katolištva] z vseh vidikov v življenjski stvarnosti?

5. Zakaj najbolj boleča, temeljna shizma - nasprotje med Cerkvijo in Sinagogo (Rim 9-11; Ef 2) - ni obravnavana tukaj, v tem dokumentu, namesto da se o odnosu Cerkve do "potomstva Abrahama« spregovori šele v odloku o »nekrščanskih religijah«?

Odlok o laiškem apostolatu

Vprašanja o pravilnem razumevanju dokumenta

1. Kaj bistveno in temeljno razlikuje laiški apostolat od apostolata celotne Cerkve - glede na zapisano v 3,1-4 o poklicanosti laikov, njihovi jus et officium $(3,4 ; 25,1)$, njihovi direktni pripadnosti Kristusu, njihovi obdarjenosti s Svetim duhom, z vero, upanjem in ljubeznijo, njihovi udeleženosti pri vseh treh Kristusovih službah in pri poslanstvu Cerkve?

2. Ali ni prav apostolat laikov genuina oblika apostolata Cerkve kot take, znotraj katerega so potem različne (cerkvene) službe? Koliko sploh lahko poleg njega obstaja nek poseben apostolat hierarhije?

3. Ali velja (po 9) zaželena actuositas [dejavnost/učinkovitost] laikov tudi za tu omenjene ženske? Po 5 in 10,1 »tako v Cerkvi kakor v svetu, tako v duhovnem kakor v časnem redu«?

4 Ali je že ustanovljen in deluje poseben sekretariat $z a$ apostolat laikov? Kritična vprašanja

1. Zakaj apostolat laikov ni utemeljen z definicijo Cerkve kot populus (grško: »laos«) Dei, kot Božjega ljudstva - namesto s sklicevanjem na njegovo nujnost v sodobnosti $(1,2)$ ? 
2. Če je Marija $(4,8)$ perfectum exemplar [popoln vzor] laiškega apostolata in je kot taka »kraljica apostolov« (torej tudi Petra in njegovih kolegov z nasledniki vred) - ali ni nujno potem govoriti o laiškem apostolatu kot nadrejenem vsem drugim oblikam apostolata Cerkve?

3. Ali ni pojem pričevalca (testimonium), ki je v tem odloku (11,2; 11,4; 13,1) uporabljan za označevanje naloge laikov, primeren za označitev naloge celotne Cerkve nasproti svetu (Dejanja 1,8; 2,32)? Tako je enkrat izrecno že v odloku $(27,1)$ : commune testimonii officium [skupna dolžnost pričevanja]!

Odlok o misijonski dejavnosti Cerkve

Vprašanja glede razumevanja

1. V kakšnem odnosu je ta odlok do konstitucije »o Cerkvi« in konstitucije »o Cerkvi v sedanjem svetu« ter deklaracije »o verski svobodi«? V njih ne najdemo izvrstne temeljne teze tega odloka $(2,1 ; 35,1$; 20,8), po kateri je Cerkev po svojem bistvu misijonska in je misijon bistvena zadeva Cerkve kot take.

2. Ali ni treba pri razvijanju te teze spomniti, da je bila Cerkev vedno bolna in nezmožna, da se zoperstavlja fizični in duhovni sili sveta takrat, kadar se je obotavljala ali sploh ni hotela biti misijonarska cerkev (Mala Azija! Severna Afrika! Vzhodni Balkan! Luteranska in reformirana ortodoksija!)?

3. Ali ni, nasprotno, kriterij pristnosti vsakega notranjega cerkvenega prenovitvenega ali reformacijskega gibanja, da se kot tako na nov način uspešno loti tudi misijonske naloge?

(Evangeličani moramo priznati, da je reformacija 16. stoletja s tega vidika zaostajala za protireformacijo - jezuiti! - in šele v 18. stoletju začela ustrezneje razmišljati in ravnati!)

4 Ali je slučajno, da je prav ta odlok (posebej 1-9)

a) tako izčrpno in prepričljivo eksegetsko dokumentiran, b) da je v njem vloga mašne daritve tako opazno zmanjšana, c) da je mariologija v tem okviru videti odvečna? 
Kritična vprašanja

1. Ponovno in ponovno: ali je res Cerkev tista, ki odrešuje in prenavlja svet $(1,1)$ ? Ali ni njena naloga, da med prvim in zadnjim Kristusovim prihodom $(9,1)$ z oznanjevanjem evangelija pričuje o Kristusu, že dovolj velika in veličastna?

2. Ali to, kar je rečeno o klicu k cerkveni enotnosti kot misijonarski nalogi $(6,6 ; 7,1)$, meri tudi na katoliško propagando med nekatoliško krščenimi novimi kristjani?

3. Ali pa je ta glede na lepo izvajane misli o ekumenizmu tudi v misijonu $(15,5 ; 29,3)$ izključena?

Izjava o razmerju Cerkve do nekrščanskih verstev

Vprašanja glede razumevanja

Kristjani ne smejo diskriminirati ali celo preganjati soljudi zaradi drugačne rase ali razreda in prav tako ne zaradi njihove nekrščanske religije $(4,11)$. Zaradi Kristusa, ki je umrl za grehe vseh ljudi in za odrešenje vseh ljudi $(4,8)$, in zaradi Boga, ki je Oče vsem $(5,1)$, moramo z njimi ravnati kot $z$ brati $(5,1)$. Njihova nekrščanska religija zasluži dostojanstvo in spoštovanje kot izraz splošnega hrepenenja po edini resnici $(1,2,2,1-2)$ : v njihovi religiji bolj ali manj vidno obstoje delne resnice, ki so žarki te edine resnice, ki razsvetljuje vse ljudi $(2,3)$. Tudi z njimi si morajo kristjani prizadevati za pogovor in morebitno sodelovanje. Mora pa jim Cerkev idensinenter [nenehno] oznanjati Kristusa kot pot, resnico in ljubezen, kot "polnost religioznega življenja«, ker je Bog v njem svet spravil s seboj $(2,3)$; oznanjati mora njegov križ kot znamenje vseobsegajoče Božje ljubezni $(4,6)$.

To je moja interpretacija Izjave in optimam partem [z najboljše strani, optimističmo]! Je v smislu koncila?

Kritična vprašanja

1. Zakaj je tako težko (morda celo nemogoče) interpretirati besedilo Izjave in optimam partem na prej nakazani način? 
2. V katerem staro- ali novozaveznem kontekstu bi lahko našli analogijo k historično-analitični predstavitvi in osvetlitvi »nekrščanskih religij«, ki prevladujeta v Izjavi?

3. Zakaj je kritična in misijonarska naloga Cerkve nasproti religijam kot takim v Izjavi le na obrobju, ne pa v njenem središču?

4. Ali ne bi (upravičeno) humani namen Izjave prišel bolje do izraza, če bi se držala preizkušene metode apostola narodov Pavla, ki je Judom in Grkom oznanjal samo Križanega, ki je umrl tudi zanje - kar je bilo za ene izziv, za druge pa norost - in jih izhajajoč iz tega nagovarjal kot ljudi in klical k sočloveškosti?

5. Kako lahko Izjava (2) nasproti primitivnim religijam povzdiguje tako imenovane "visoke religije" - kar je v religiologiji že davno opuščeno -, ko pa slednje izraziteje in nevarneje nasprotujejo besedi (s) Križa?

6. Kako lahko Izjava $(4,1) \mathrm{z}$ ozirom na zgodovino in sedanjost Izraela govori o njegovi "nekrščanski religiji« hkrati s hinduizmom, $\mathrm{z}$ budizmom, muslimanstvom, ko pa a) v Stari zavezi ne gre za neko »religijo«, ampak za prapodobo enega Božjega razodetja, b) v obstoju kasnejšega in današnjega (vernega ali nevernega) judovstva pa za edini naravni (svetovno zgodovinski) dokaz za Boga?

7. Ali ne bi bilo zaradi Judom sovražne drže stare, srednjeveške in tudi še moderne Cerkve tu mesto za izrecno izpoved krivde (mnogo bolj kot nasproti krščanskim ločenim bratom)?

8. In v 3,2 pri omembi muslimanov mesto, da se spomni na fatalno vlogo Cerkve v tako imenovanih križarskih vojnah?

Izjava o verski svobodi

Vprašanje glede razumevanja

Koncil se z Izjavo ne obrača h kristjanom oziroma k Cerkvi, temveč $(1,3)$ v njihovo dobro na državne oblasti (govori torej pro domo). Od njih zahteva za kristjane oziroma Cerkve svoboden prostor, ki pritiče potrjevanju in širjenju njihove vere kot edino prave religije $(1,2-3 ; 15,1)$. To zahtevo utemeljuje s sklicevanjem na naravno dostojanstvo človeške osebe $(2,2 ; 15,2)$. Verska svoboda človeške osebe je v razodetju potrjena in osvetljena indirektno: $\mathrm{z}$ bistvom vere in ravnanjem Kristusa in apostolov 
(10-11) in jo je tudi Cerkev v načelu vedno zastopala. To versko svobodo zahteva kot vsem ljudem - tudi nekatoličanom in njihovim organizacijam -, predvsem pa katoliškim kristjanom in katoliški cerkvi pripadajočo pravico, ki mora biti zakonsko-pravno urejena in dosledno spoštovana od državnih oblasti. Državne oblasti Izjava pouči, da je izpolnjevanje te zahteve v njihovem lastnem interesu $(6 ; 8,3 ; 15,4)$.

Sem prav razumel in povzel smisel in namen te Izjave?

Kritična vprašanja

1. Ali je Cerkev (ne le katoliška!) zaradi dolge zgodovine, ko je v njeni povezanosti z državo prevladovalo "cogite intrare " [»prisilite jih vstopiti«], legitimirana, da postavlja to zahtevo [po zagotavljanju verske svobode]? Ali ne bi bilo tu mesto za kar obsežno izpoved in priznanje krivde? Ali res zadošča stavek 12,1: „Čeprav najdemo v življenju Božjega ljudstva [...] včasih tako ravnanje, ki je z evangeljskim duhom manj skladno, še več, ki mu je celo nasprotno, je Cerkev vendar vedno učila, da ni nikogar dovoljeno siliti $k$ veri.«

2. Kdaj in kje so staro- in novozavezni pričevalci zahtevali pravno zagotovljen prostor za življenje in oznanjevanje svoje vere (in za zastopanje drugih religij)?

3. Kdaj in kje so svojo dejansko svobodo utemeljevali s sklicevanjem na naravno dostojanstvo človeške osebe?

4. Kdaj in kje so versko svobodo priporočali kot nekaj, kar da je v interesu vladajoče oblasti same?

5. Kdaj in kje so se na prisilo in pritisk s strani vladajoče oblasti, ki je ogrožala njihovo svobodo, odzivali drugače kot tako, da so se temu upirali s trpečim prenašanjem?

6. Zakaj v Izjavi (razen v zadnjem stavku 15,5) ni nobene besede o pra$v i$ svobodi, h kateri nas je osvobodil Sin (Jn 8,36), in ki je tam, kjer je Gospodov Duh (2 Kor 3,17): besede o osvobajajočem »zakonu duha življenja v Kristusu Jezusu« (Rim 8,2), v katerega Cerkev vztrajno "gleda" (Jak 1,25), ki pa je tudi njena lastna kriza/stiska (Jak 2,12) skratka o "veličastni svobodi Božjih otrok« (Rim 8,21)? 
7. Ali ne bi Cerkev - ki je poklicana k tej svobodi $(\mathrm{Gal} 5,13)$ in v njej obstoji (Gal 5,1) -, ki bi govorila sebi in s sabo, nasproti državnim oblastem in vsemu človeštvu, $\mathrm{z}$ večjo močjo pričala tudi za t. i. »versko svobodo«, kot se je to zgodilo v tej Izjavi?

\section{Pismo o mariologiji}

Spoštovani, dragi gospod kolega!

Kmalu po moji vrnitvi iz Rima je prispela na moj naslov Vaša Mariologija: takoj sem se lotil branja in bral z napetostjo, $s$ kakršno sem v prejšnjih desetletjih bral kriminalke (!), od prve pa do zadnje strani.

Naj vam pred vsem drugim povem, da lahko mirne vesti zatrdim: Vaše delo zanesljivo priča o sistematični nadarjenosti, moči in spretnosti svojega avtorja. Kdor zna neko temo - ne glede na moj odnos do nje - obdelati tako metodično in stvarno, dosledno in pregledno, kot je uspelo Vam - temu ni treba dvomiti o mojem spoštovanju. Razveselil sem se tudi Vašega razsodnega in dostojanstvenega spoprijema s starejšimi in novejšimi »mariologi« in prav tako poštenosti, ki ste jo pokazali, ko ste ob »historičnih « problemih rekli, kar je bilo treba reči. Posebno proti koncu dela sem našel kar nekaj stavkov, ob katerih bi moral na robu učiteljsko pohvalno pripisati: „dobro« (če bi odmislil kontekst, v katerem so bili napisani). Seveda mi je ugajalo, ko sem opazil, kako se povsod trudite, da bi celoto navezali in naravnali na kristološko sredico, iz katere je vaša tema nekoč izšla. Sam bi seveda rekel, da se ji je pri tem izneverila. V toliko vse dobro - če namreč »mariologija« sploh lahko legitimno postane in ostane teološka tema. Če bi jo lahko kot tako priznal, bi kvečjemu izrazil pomislek glede načina, kako ločujete in povezujete "zgodovino« in "vero«. Ko to počnete (tudi v Rimu sem opazil, da ne edini med mlajšimi katoliškimi teologi našega časa!), stopate na zdrsno strmino, ki pelje k Schleiermacherju in Bultmannu in na kateri ne morete pričakovati dobrih sadov, pa najsi gre za Vašo temo (ki mi kot taka sicer ni sprejemljiva) ali za obravnavo pristnih teoloških problemov.

Dragi gospod kolega, od mene želite »izčrpno kritiko«. Kako naj Vam ustrežem, ko pa še vedno ne morem sprejeti Vaše predpostavke o mož- 
nosti, opravičenosti in nujnosti »mariologije« kot take. Tako dobro kot jaz veste - in to tudi priznate -, da je »theotokos « [»Bogorodica»] koncila $\mathrm{v}$ Efezu (in v običajnem pomenu tudi že pred koncilom) pomožna kristološka formula in ne samostojna dogma, ki bi jo hotel koncil razglasiti poleg tega, kar je kot dogmo opredelil v zvezi s Kristusovima »dvema naravama«. Ko pa se to theotokos uporabi - in moram reči: zlorabi - mariološko, postane izhodišče nekega razvoja, ki ga lahko razumem le kot divjo rast, pa čeprav je bila in je theotokos sama po sebi nesporna. Ta divja rast, kot jo tudi sami opisujete, sčasoma postane tako objestna, da začne neizogibno ogrožati deblo, iz katerega raste, namreč Božje delo in besedo v Jezusu Kristusu. »Dekla Gospodova« iz Lukovega evangelija je postala nosilka svoje lastne krone, na kateri naj bi odkrivali vedno nove in nove bisere - vse do tistih, ki sta jih ugotovila Pij XII. leta 1950 in Pavel VI. med II. vatikanskim koncilom. Tega ne morejo spremeniti še tako gostobesedna opozorila, da gre pravzaprav za hvalnico njenemu sinu. Zdi se mi, da je Cerkev in cerkvena teologija tej služabnici vzela njeno najboljše, ko jo je naredila za kraljico, za »Kraljico nebes « v neizogibni konkurenci $\mathrm{z}$ »Očetom našim, ki si v nebesih«. In zdi se mi, da bolj ko je ta nenavadno izumljena in okinčana figura v svetu »pobožnosti« postala predmet čaščenja (dulia in hyperdulia), bolj ko se je torej cerkveno učiteljstvo (kot leta 1855 in 1950) lahko sklicevalo na soglasje Cerkve, na consensus ecclesiae kot način Božjega razodevanja toliko bolj komplicirana, izumetničena in mukotrpna je morala postati naloga teologije to make the best of it: naknadno utemeljiti in pojasniti s strani Cerkve uradno priznane lastnosti in zmožnosti te figure, se z distinkcijami zavarovati pred napačnimi pojmovanji, ki se kar ponujajo, v najboljših primerih (kot je Vaše predavanje) pokazati na nujnost njene navezave na sredico Božjega delovanja in razodetja.

Oprostite mi, da tako pravim: tudi Vaša »mariologija « mi ne da vtisa, da bi Vas pri njeni izdelavi vodila neka druga »ananke« [nuja] (1 Kor 9,16) kot dejstvo cerkvene veljavnosti kar štirih Marijinih dogem - in to ob vsej vaši pokončnosti, ki Vam je zares ne odrekam, in ob vsej tehnični perfekciji, ki jo pri Vas občudujem. Prej dajete vtis, da ste nasproti tej danosti tudi Vi v resni zadregi (in ne le najin skupni prijatelj ...). 
$S$ preprostostjo vere, ki je gotova svoje stvari, zmore, sme in mora tudi znanstveni dogmatičar govoriti bolj sproščeno, bolj brez varovalk in določneje, kot govorite Vi v tem primeru. Omenjeni prijatelj, ki se, kot veste, "mariologiji«, kar se da, izogiba, ima pretanjen občutek, da gre za trhlo tvorbo, ki je od vsega začetka obsojena na odmrtje. Upam si napovedati, da tega Vašega predavanja ne boste imeli še enkrat, pa čeprav je zanimivo. Ni slučajno, da je Vaticanum II sicer pogosto obvezno komemoriral marijansko konstrukcijo, a je pri svojih pomembnih izjavah očitno ni potreboval, ali kvečjemu za dekoracijo. Podoben vtis sem dobil, ko sem v Rimu v ožjem krogu poslušal kolega ..., ko sta diskutirala o svojih marioloških pogledih (ki niso bila ravno v soglasju). Katoliška cerkev ( $\mathrm{k}$ sreči tudi za Vas) ne stoji in pade $\mathrm{z}$ »mariologijo«. In tudi vi, dragi kolega, ne stojite in padete $\mathrm{z}$ njo.

V Baslu, 21. oktobra 1966

S prisrčnim pozdravom Vaš Karl Barth.

Iz nemščine prevedel Marko Kerševan

https://doi.org/10.26493/2590-9754.14(28)219-242 